\title{
Seeking Internationalization: The State of Canadian Higher Education
}

Tim Anderson

University of British Columbia

\begin{abstract}
This article explores the internationalization of Canadian universities, with a focus on the rise of foreign postsecondary students in Canada, the economic impacts, and the various benefits, challenges, and adjustments that have been influenced by the continuing demographic shifts on Canadian campuses since 2000. Rooted in recent global and Canadian higher education internationalization trends, this paper suggests that accommodations for such shifts have not kept pace with the influx of culturally and linguistically diverse foreign students, whose population growth rate outpaces domestic university students' by several times. I conclude with unresolved dilemmas that continue to pose challenges for Canadian universities, and with suggestions for manageable supports to ensure the needs of students are responsibly balanced with the economic constraints of universities.
\end{abstract}

\section{Résumé}

Cet article explore l'internationalisation des universités canadiennes en mettant l'accent sur l'augmentation du nombre d'étudiants étrangers au Canada au niveau postsecondaire, les conséquences économiques, ainsi que la variété d'avantages, de défis et de modifications marqués par l'évolution démographique sur les campus canadiens depuis l'an 2000. Prenant pour base les tendances récentes à l'internationalisation dans l'enseignement supérieur au Canada et dans le monde, cet article soutient que les aménagements entrepris face à cette évolution n'ont pas réussi à suivre l'afflux des étudiants étrangers, de cultures et de langues diverses, et dont le taux de croissance dépasse plusieurs fois celui des étudiants domestiques. L'article se conclut par une discussion des dilemmes irrésolus représentant encore des défis pour 
les universités canadiennes, et par des propositions de soutiens gérables afin de s'assurer que les besoins des étudiants s'équilibrent de façon responsable avec les contraintes économiques des universités.

\section{Introduction}

The proliferation of global student mobility and academic cosmopolitanism continues to significantly alter the landscape of Canadian universities. Between 2000 and 2011, foreign student ${ }^{1}$ populations grew over 99\% in Canada, from 89,532 to 178,491-more than doubling domestic university students' $37 \%$ growth (Statistics Canada, 2013a, 2013b). Over this period, tuition fees for international students ${ }^{2}$ have accordingly skyrocketed to address and take advantage of the growth in international students wishing to attend Canadian universities. These high tuition fees have been necessitated (or at least justified) by ongoing budget cuts to public universities (CAUT, 2013; Kiley, 2011; Thompson \& Bekhradnia, 2010) and mitigated by the significant educational and social capital of Canadian universities and their ability to attract globally mobile students. Figures 1 and 2 outline the changing revenue streams of Canadian universities between 2000 and 2012. Although federally allotted postsecondary funding as a proportion of GDP has declined considerably since the early 1990 os (CAUT, 2013), it has remained generally static since 2000 as a percentage of total university revenues (Statistics Canada, n.d.). The most notable changes have instead come with reductions in non-federal funding to Canadian universities (such as provincial and municipal grants and allocations) and other sources, including donations, investments, endowments, and non-governmental grants. In contrast to these reductions, there have been equally significant increases in revenues generated by student tuition fees. Since 2000, profits from tuition rose five percent as a proportion of total university revenues, from just under four billion to over eight billion dollars in 2012-2013 $3^{3}$ when adjusted for inflation (see Figures 1 and 2).

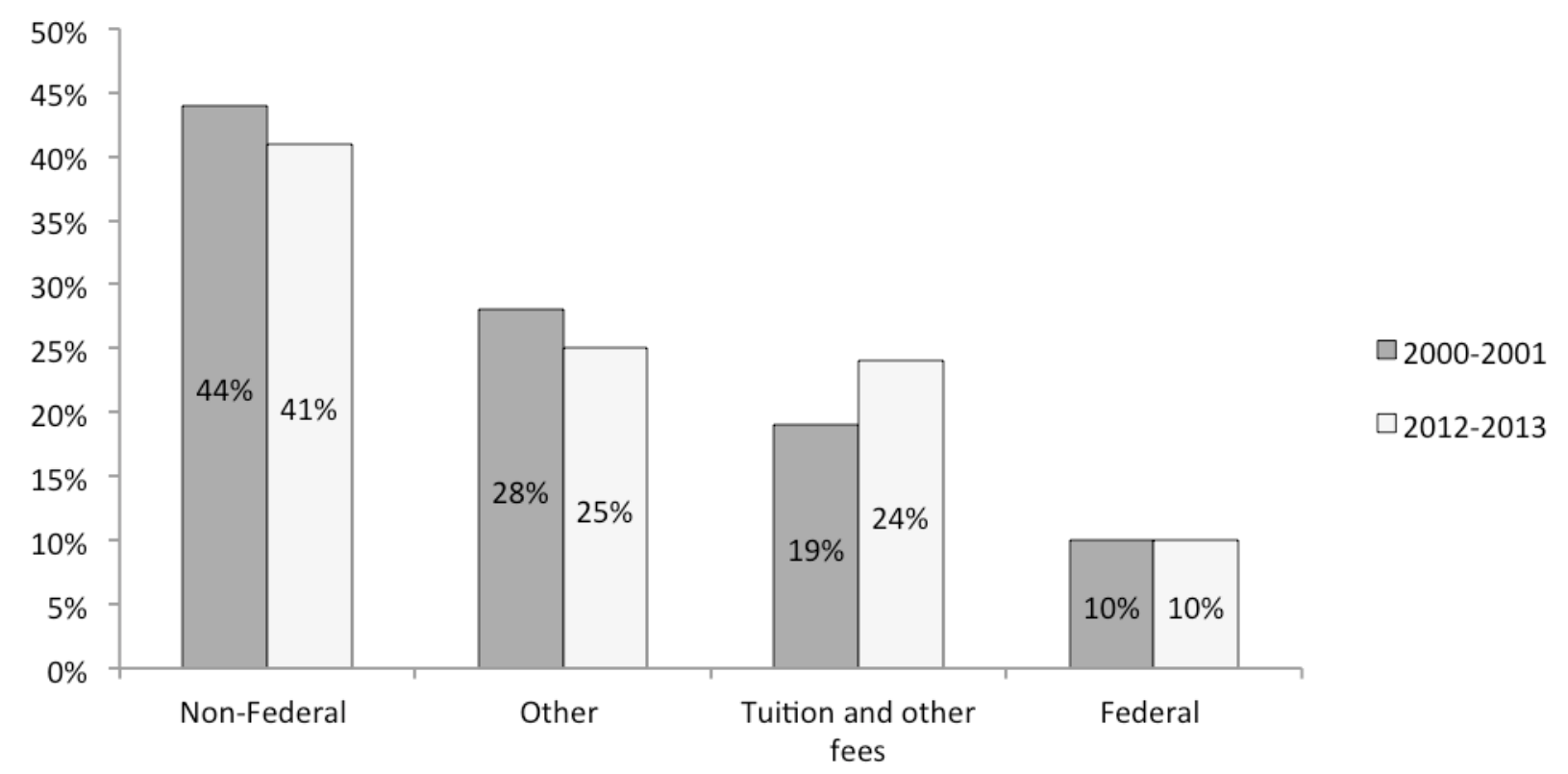

Figure 1. Percentage of total revenues of universities and degree-granting colleges (2013 dollars) (Statistics Canada, 2014a) 
$\$, 000(2013)$

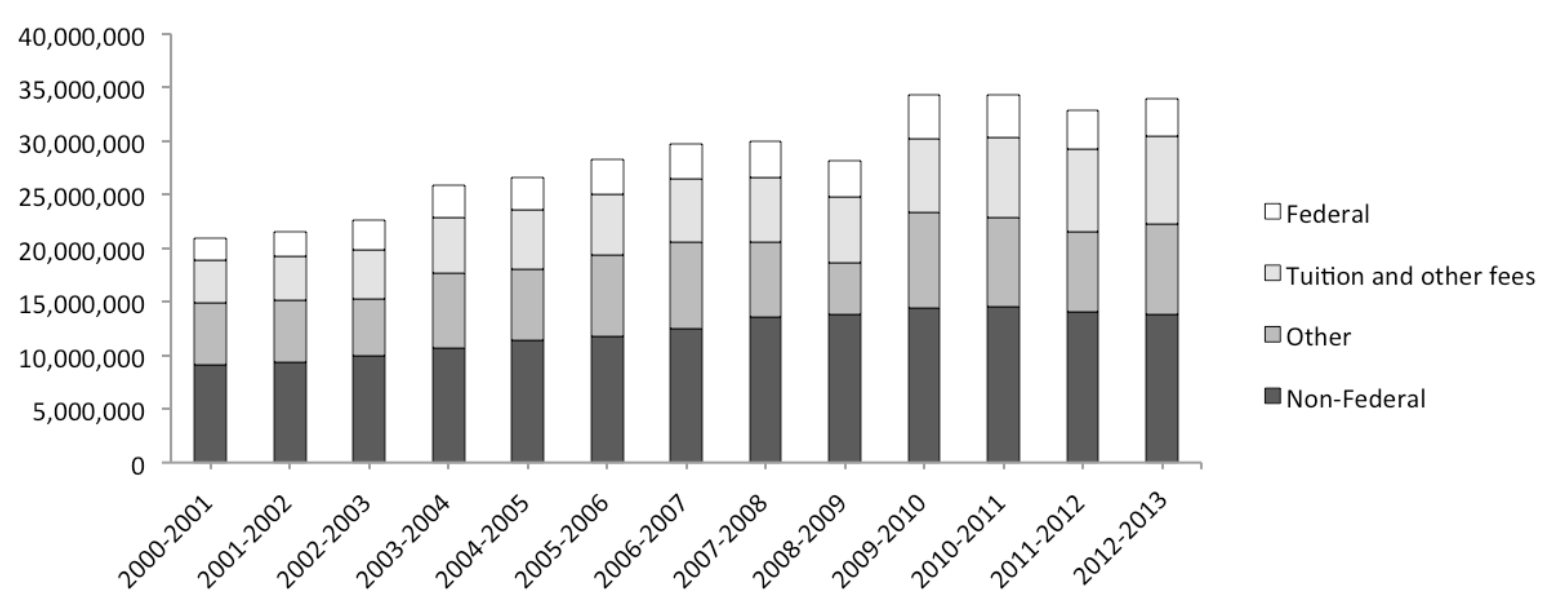

Figure 2. Annual revenues by type of funds of universities and degree-granting colleges (2013 dollars x1,00o) (Statistics Canada, n.d.)

A considerable portion of these rising tuition revenues have derived from international students, who typically pay three to four times that of domestic students, with international undergraduate students' annual tuition costs averaging \$18,462 in 2012-2013 compared to $\$ 5,646$ for their Canadian peers (Statistics Canada, 2014a, 2014b). International graduate student tuition costs were also considerably higher, at $\$ 13,299$ compared to $\$ 5,979$ for Canadian students. Although changes to the Statistics Canada survey universe make comparisons of pre- and post-2006 tuition data difficult, ${ }^{4}$ Figure 3 provides a general look at the rising tuition fees for international and domestic students since 2000 (with two sets of data, to account for Statistics Canada's survey changes). Adjusted for inflation, tuition for Canadian undergraduate students remains the lowest, slightly behind Canadian graduate students', while international undergraduate students have experienced the largest and fastest-growing increases, from paying just under $\$ 12,000$ in 2000-2001 to almost $\$ 18,500$ in 2012-2013.

\$(2013)

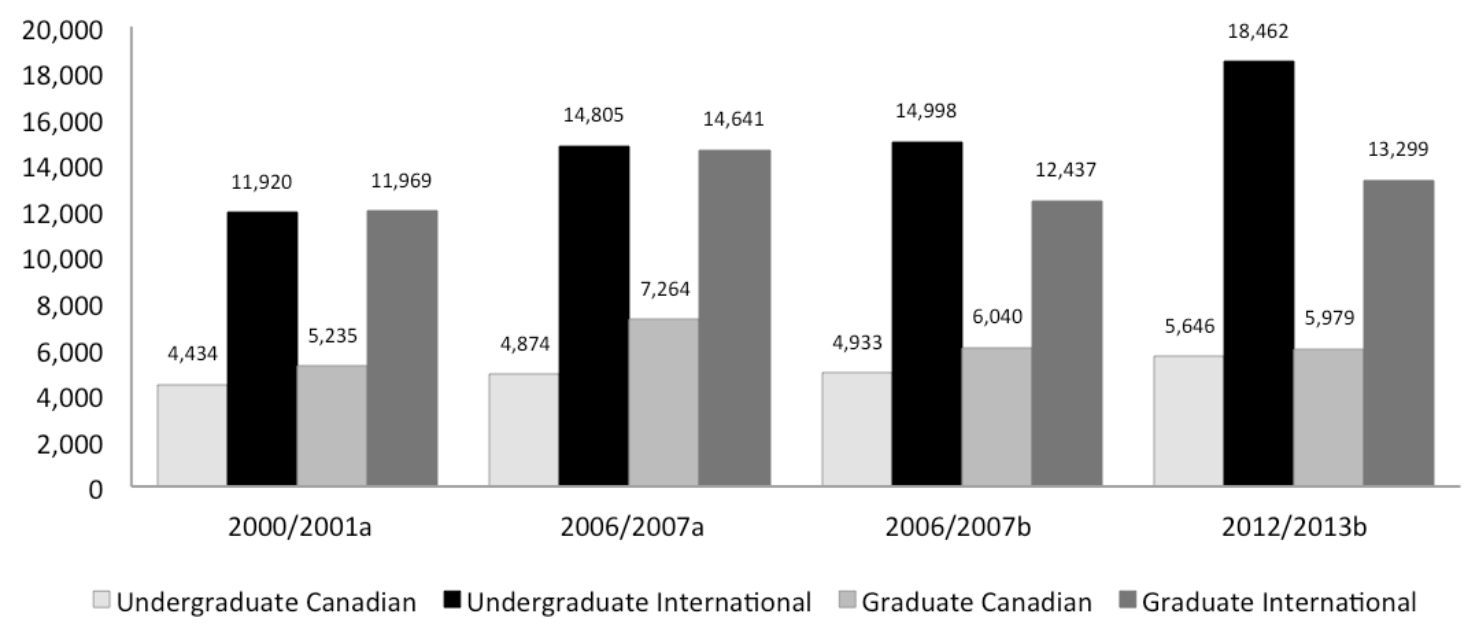

Figure 3. Canadian tuition fees, 2000-2001 to 2012-2013 (2013 dollars) (Statistics Canada, 2014a, 2014b) 
Although the differential fee structures for international and Canadian students are in part due to the public subsidization of higher education in the country, they also reveal the ongoing corporatization of higher education as universities search for alternative revenue sources (Altbach \& Knight, 2007)-issues that reflect the broader marketization of western universities across various spheres of management, leadership, decision making, (intellectual) property structures, research, and funding (Marginson, 1999). This ongoing neoliberal imagining of Canadian higher education, while certainly not a new phenomenon, can pose challenges for universities regarding the need to balance fiscal pressures with their social and educational responsibilities to students. The extent to which universities have or have not been able to adapt to and accommodate the shifting student demographics in this era of hyper-internationalization remains an area of concern, particularly for some culturally and linguistically diverse (CLD) students who speak English as a second (L2) or additional language. The promotion of postsecondary-level internationalization $^{5}$ in Canada has therefore created an ethical tension between the various benefits of larger numbers of foreign students versus the potential challenges and accommodations of adapting to increasingly diverse university populations. The following explores these issues in greater detail against the recent backdrop of Canadian and global higher education internationalization trends since 2000.

\section{Global Perspectives}

The increase of globally mobile students has unfolded steadily over the last several decades with the most dramatic changes occurring since 2000 (see Figure 4). Most areas of the globe have experienced considerable growth at the postsecondary level, with Asia, North America, and Europe the leaders in attracting foreign students to their universities. Between 2000 and 2011, Asia's share of enrolled foreign tertiary students grew 133\% from 214,744 to 500,947, compared to Europe's 121\% increase from 920,140 to 2,033,082, and North America's 60\% growth from 569,640 to 913,464 (OECD, 2013a). Increases were not confined to these areas, however, as the total global population of foreign tertiary students grew over 100\% between 2000 and 2011, from 2,071,963 to 4,265,579 (OECD, 2013a). Predictions for future growth suggest few signs of abatement, with estimates ranging from 6.4 to 8 million students studying outside their countries of citizenship by the year 2025 (Goddard, 2012; OECD, 2009).

The United States maintained its spot as the most popular single-country destination for foreign tertiary students, with 709,565 students in 2011 (despite a six percent drop in global market share between 2000 and 2011, from 23\% to 17\%), while in the same year continental Europe attracted nearly 50\% of all foreign tertiary students studying abroad (OECD, 2013b). Canada's global market share grew only marginally during this period, from $4.6 \%$ to $4.9 \%$ (OECD, 2013a, 2014), despite significant net increases in total enrolled foreign student populations nationally-as outlined in the forthcoming sections. Overall enrolments of international tertiary students in Canada as a percentage of total tertiary enrolments sits at $8.2 \%$, slightly higher than the 2011 OECD average of $6.9 \%$ and more than double that of the United States at 3.4\% (OECD, 2013a, 2014). The regions of origin for global foreign tertiary students, however, paint a significantly different picture from the regions of destination, with the vast majority of foreign students (approximately 75\%) 
originating from non-OECD countries ${ }^{6}$ (OECD, 2013b). This outlines the disproportionate amount of symbolic and economic capital that OECD countries and their postsecondary institutions have for both fellow members and non-members alike. Fuelled strongly by China and its rapid liberalization and economic growth over the last two decades, Asia leads the world, with 2,149,708 tertiary students studying abroad, accounting for 50\% of global totals. China is the largest single-country supplier of foreign tertiary students, with 722,915 people engaged in cross-border study as of 2011; comprising almost $17 \%$ of global totals, more than three times higher than its closest rival country, India, and over five times higher than the next largest sending countries, Korea and Germany (OECD, 2013b).

\section{Millions}

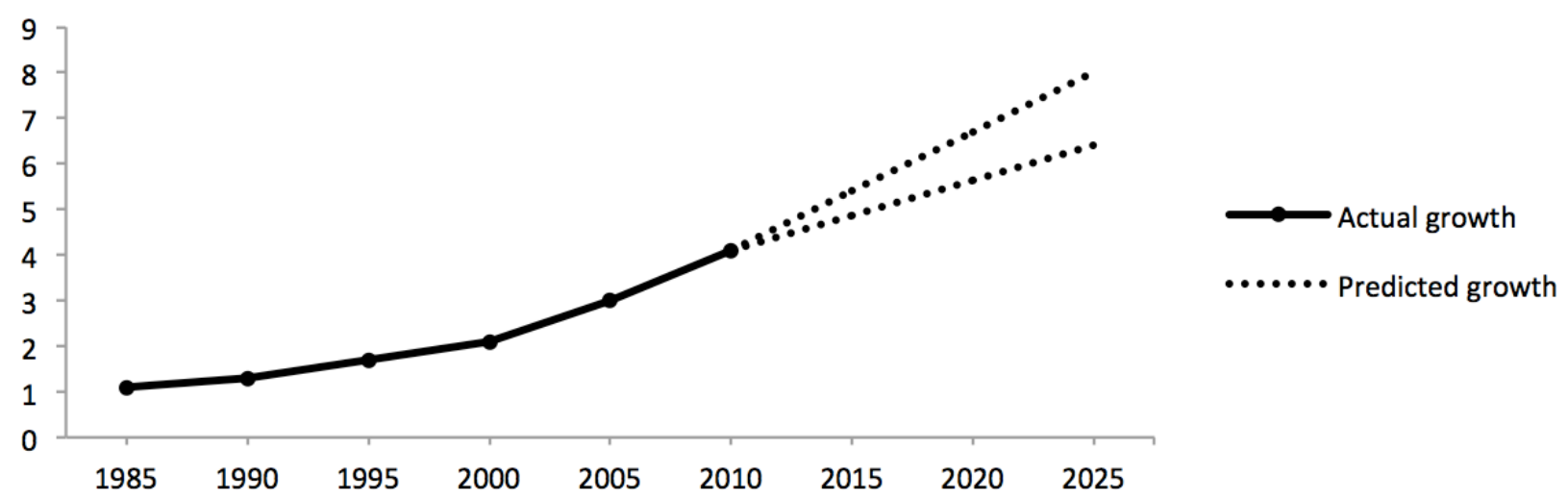

Figure 4. Global growth in foreign tertiary education (Goddard, 2012; OECD, 2009)

\section{Canadian Perspectives ${ }^{7}$}

The Canadian federal government's internationalization policy continues to revolve around the positive economic contributions of international students and the desire to increase innovation through the recruitment of skilled foreign professionals (Citizenship and Immigration Canada, 2011; Foreign Affairs, Trade and Development Canada, 2011, 2012, 2014). Although Canada's overall market share of foreign tertiary student enrolments remains relatively modest in global terms, these students' contributions to the Canadian economy have been considerable. In 2010 alone, international student expenditures contributed $\$ 7.7$ billion to the Canadian economy, $\$ 445$ million of that being direct governmental revenue, with an estimated creation or maintenance of 81,000 jobs (Roslyn Kunin \& Associates, 2012). In addition to the more tangible economic benefits, internationalization positively impacts Canadian universities by providing domestic students access to a variety of perspectives, languages, cultures, and experiences that foreign students bring with them to campuses-perspectives that have potential entrepreneurial, educational, and intellectual impacts. In a sense, internationalization brings the world to Canada without Canadian students ever having to leave. Foreign students who return to their countries of birth (or go elsewhere) after studying in Canada may also become future allies, collaborators, or business partners with Canadian academics, governments, or industry. 
Canada wants to transmit to highly educated and skilled foreign students the allure of the country and its institutions in hopes of improving Canada's attractiveness and influence on the global stage, including the targeted migration of talented students to the country, particularly at the graduate level. Shifts in Canadian immigration policy have accordingly become more aggressive in actively encouraging international graduate students to come to Canadian universities by making migration more accessible than in the recent past. In November 2011, the Canadian federal government announced a revised international graduate student recruitment policy that outlined a plan to attract up to 1,000 additional international $\mathrm{PhD}$ students per year to Canadian universities as permanent residents (PR) through the Federal Skilled Worker Program (Citizenship and Immigration Canada, 2011). The Canadian Minister of State at the time, Gary Goodyear, speaking of this program, noted that "[d]octoral graduates play a unique role in the economy. They drive research, encourage innovation and pass on their knowledge through teaching. . . . And quite simply, Canada needs more of them" (Citizenship and Immigration Canada, 2011, p. 2). The recent announcement of the federal government's International Education Strategy is similarly aimed at enticing international researchers and students to Canada through the strengthening of the Canadian education "brand" globally-with targeted recruitment focusing on six emerging markets (Brazil, China, India, Mexico, North Africa and the Middle East, and Vietnam) - and through providing enhanced funding opportunities for researchers and students who come (Foreign Affairs, Trade and Development Canada, 2014).

This imperative to increase the presence of international students in Canada appears to be working. Table 1 outlines overall Canadian and foreign student enrolments in Canadian universities between 2000 and 2011, with foreign students doubling their population in just 11 years. Table 2 further delineates enrolment classifications into six categories and their corresponding growth percentages since 2000. Canadian undergraduate students remain the largest population quite substantially. International student numbers, however, have increased most dramatically over this period, including $167 \%$ growth for undergraduate students and $114 \%$ growth for graduate students-numbers that are especially resonant for Canadian universities due to the elevated tuition fees for international students, particularly at the undergraduate level. While total enrolments for domestic students remain considerably higher, the discrepancy in growth percentages between domestic and foreign university students in Canada is in line with global trends more generally, and it fits well with university and government mandates to further internationalize Canadian campuses.

Table 3 details the continent of origin of foreign students in Canadian universities since 2000. Similar to global trends (OECD, 2013b), continental Asia is the largest source of students for Canadian universities, providing 88,224 in 2010-2011-nearly as much as every other region of the globe combined. Table 4 notes the top five countries of origin for foreign students between 2000-2001 and 2010-2011, with students from China forming the largest group, comprising $19 \%$ of all foreign university students in Canada and exhibiting a $176 \%$ increase in that period. 

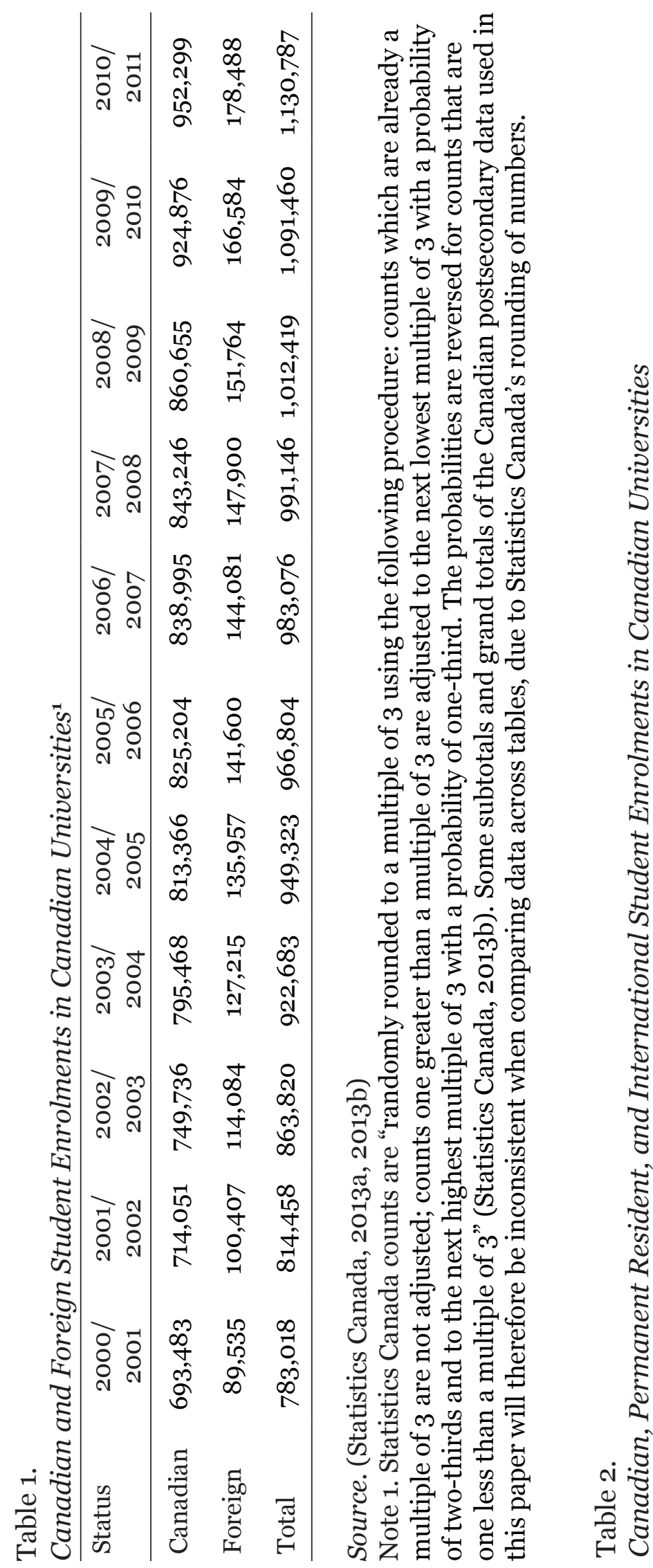

\begin{tabular}{|c|c|c|c|c|c|}
\hline ১ং & m & is & $\begin{array}{l}+ \\
0\end{array}$ & & $\underset{\exists}{ت}$ \\
\hline $\begin{array}{ll}0 & -1 \\
0 & -1 \\
0 & 0 \\
\text { N } & \\
\text { N }\end{array}$ & 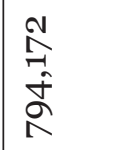 & 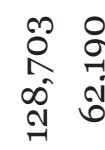 & 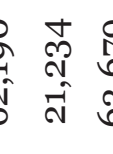 & $\begin{array}{l}a \\
\hat{b} \\
\text { กิ }\end{array}$ & 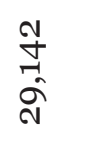 \\
\hline 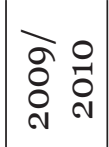 & $\begin{array}{l}\text { N } \\
\text { O } \\
\infty \\
\text { O } \\
\text { N }\end{array}$ & 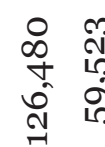 & 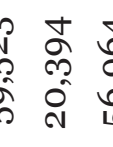 & $\begin{array}{l}\text { पे } \\
0 \\
0 \\
10\end{array}$ & 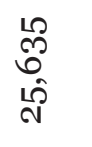 \\
\hline 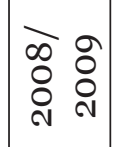 & $\begin{array}{l}N \\
\hat{N} \\
0 \\
\hat{N} \\
N\end{array}$ & 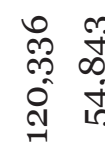 & 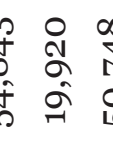 & \begin{tabular}{l}
$\infty$ \\
\multirow{1}{*}{} \\
0 \\
0
\end{tabular} & $\begin{array}{l}\text { จ } \\
\text { ผิ } \\
\text { ลิ }\end{array}$ \\
\hline 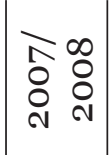 & $\begin{array}{l}0 \\
\hat{0} \\
\hat{0} \\
0\end{array}$ & 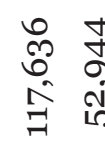 & 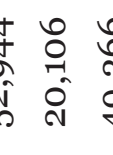 & 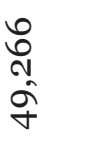 & $\begin{array}{l}\text { +े } \\
\text { aे } \\
\hat{\text { N }}\end{array}$ \\
\hline $\begin{array}{ll}\widehat{O} & \hat{0} \\
0 & 0 \\
0 & 0 \\
\text { ㄱ. }\end{array}$ & $\begin{array}{l}0 \\
0 \\
+ \\
0 \\
1 \\
1\end{array}$ & $\begin{array}{cc}0 & \infty \\
\infty & 0 \\
\infty & 1 \\
0 & 1 \\
\ddots & 1\end{array}$ & 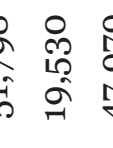 & 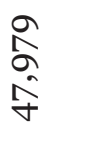 & $\underset{\hat{H}}{+\sqrt{+}}$ \\
\hline 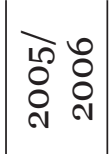 & $\begin{array}{l}\text { N } \\
0 \\
0 \\
\tilde{N} \\
0 \\
\hat{1}\end{array}$ & 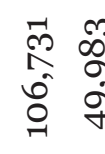 & 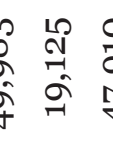 & $\begin{array}{l}\stackrel{\circ}{a} \\
\stackrel{\gamma}{\gamma}\end{array}$ & 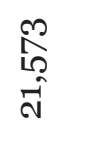 \\
\hline 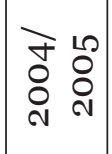 & $\begin{array}{l}\hat{0} \\
12 \\
\hat{2} \\
\hat{\sigma}\end{array}$ & 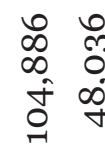 & 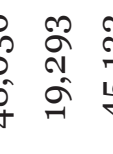 & \begin{tabular}{l}
\multirow{2}{*}{} \\
$\stackrel{\sim}{+}$ \\
$\stackrel{f}{\sigma}$
\end{tabular} & 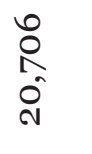 \\
\hline 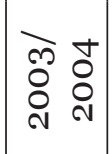 & $\begin{array}{l}\infty \\
\infty \\
\infty \\
\infty \\
\infty \\
0\end{array}$ & $\begin{array}{ll}10 & 15 \\
0 & 1 \\
\infty & 0 \\
\infty & 1 \\
0 & 7\end{array}$ & 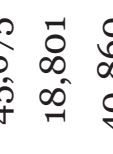 & $\begin{array}{l}0 \\
0 \\
\infty \\
0 \\
\dot{y}\end{array}$ & $\begin{array}{l}\text { No } \\
\text { m̃ } \\
\text { ô }\end{array}$ \\
\hline 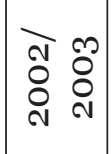 & \begin{tabular}{l} 
J \\
$\infty$ \\
$\sigma$ \\
$\hat{1}$ \\
\multirow{1}{0}{}
\end{tabular} & 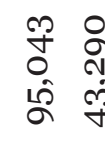 & 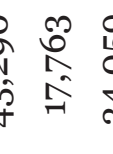 & $\begin{array}{l}0 \\
0 \\
0 \\
\dot{j}\end{array}$ & $\begin{array}{l}\stackrel{1}{N} \\
\stackrel{1}{0} \\
\stackrel{n}{n}\end{array}$ \\
\hline 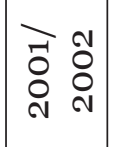 & $\begin{array}{l}\text { n } \\
60 \\
0 \\
0 \\
6\end{array}$ & $\begin{array}{ll}9 & v \\
0 & 1 \\
\infty & - \\
\infty & 0 \\
\infty & f\end{array}$ & 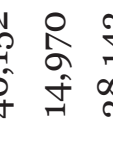 & $\begin{array}{c}\underset{P}{ \pm} \\
\underset{\sim}{ \pm} \\
\text { N }\end{array}$ & $\begin{array}{l}10 \\
\stackrel{1}{1} \\
10 \\
10\end{array}$ \\
\hline 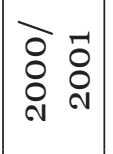 & 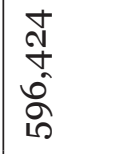 & 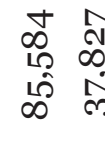 & 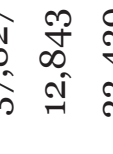 & 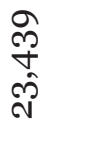 & 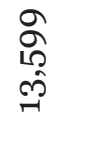 \\
\hline 足 & 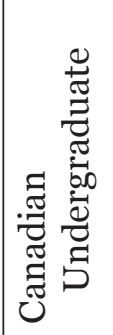 & 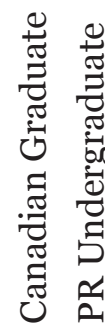 & 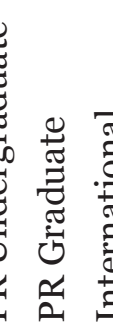 & 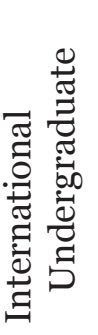 & 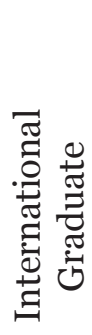 \\
\hline
\end{tabular}



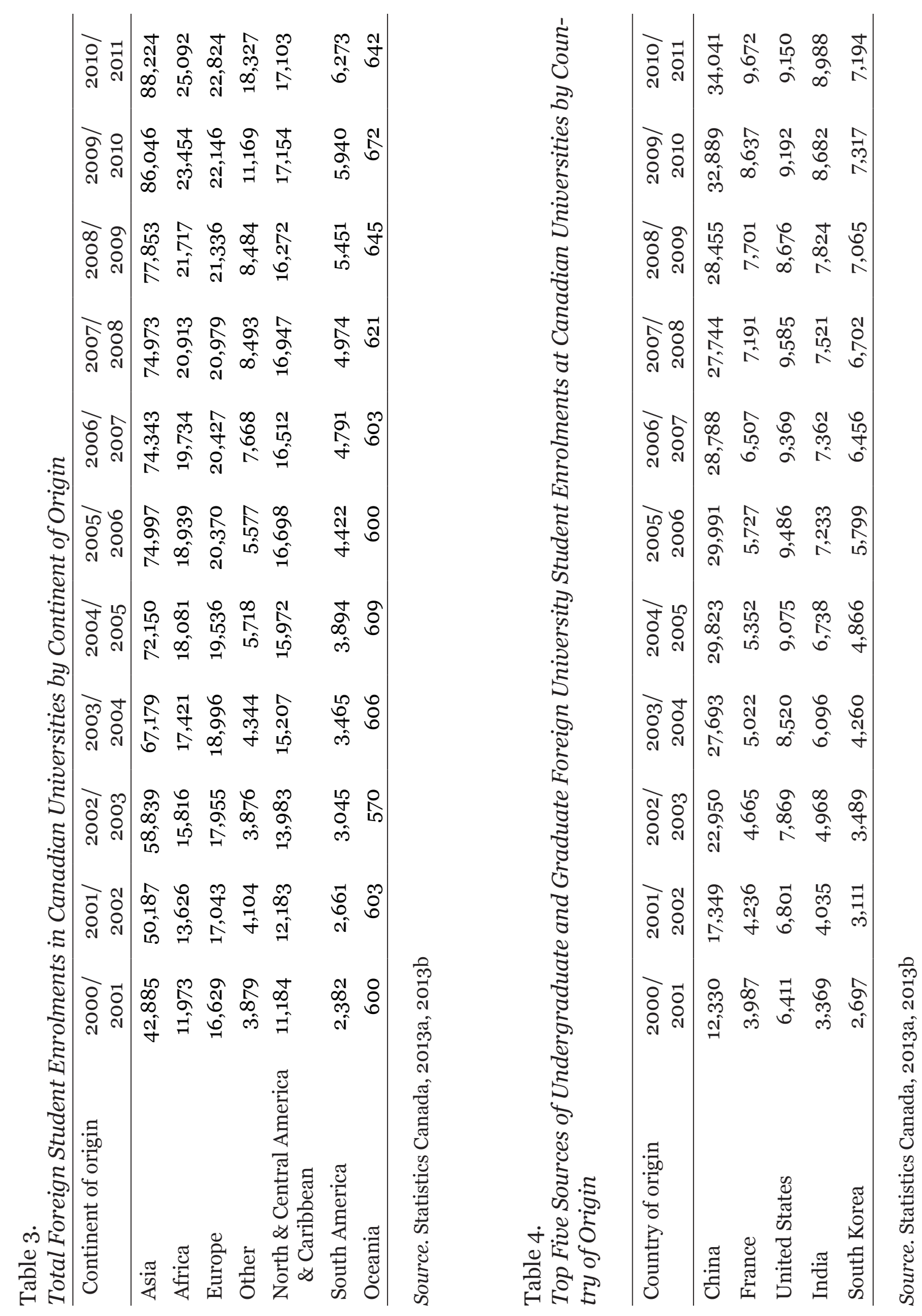
At the graduate level, China remains the largest provider of foreign students, with a total of 6,762 in 2010-2011 (see Table 5). Interestingly, and at odds with the overall growth trends of Chinese tertiary students globally, foreign Chinese graduate students in Canada peaked in 2003-2004 at 9,726 and have declined steadily since, with only marginal gains in 2009-2010, followed by further declines the following year. The result has been a 30\% reduction in Chinese graduate students from peak numbers a decade ago. Table 6 specifies the broader grouping of foreign Chinese graduate students into their respective "international" and "permanent resident" categories. Since 2003, the number of international Chinese graduate students has risen by $29 \%$, notably less than the overall international graduate student growth of 114\% (Statistics Canada, 2013b). Permanent resident Chinese graduate students have declined $62 \%$ over this period, while the other four top source countries for PR graduate students in Canada (Iran, India, France, and the United States) have all increased considerably (Statistics Canada, 2013a). This dip appears likely to correspond to the decline in overall PR populations from China since the early 2000s, as noted in Figure 5. Causes for the stagnant growth in Chinese international graduate students in Canada appear slightly more varied. The 985 Project, an initiative of the Chinese government to improve the quality and reputation of its elite universities through large injections of financial capital, may be influencing an increasing number of Chinese students to remain in China as opposed to studying abroad. The presence of English-medium satellite universities and branch campuses in China is similarly providing alternative high-quality opportunities for Chinese students wanting international experiences without the exceptionally high costs associated with overseas study in western universities (Mok, 2007; Stanfield \& Shimmi, 2012). The number of postsecondary institutions has also grown considerably over this period in China, from 599 in 2000 to 1,112 in 2010, as have domestic graduate university populations, which increased $430 \%$ between 2000 to 2010 from 283 ,000 students to over 1.5 million (Stanfield \& Shimmi, 2012). Factoring in these changes with the rising Canadian tuition costs for international graduate students (particularly at the master's level), the marginal growth of foreign Chinese graduate students in Canada highlights the various "push-pull" factors that motivate or constrain students' mobility decisions with respect to international education. These trends, however, should still concern Canadian graduate programs in terms of attracting top (Chinese) talent to Canadian universities and to Canadian job markets post graduation, particularly as the Canadian government continues to pursue growth in Chinese student enrolments against the backdrop of the AsiaPacific Gateway initiative and the goal to strengthen economic supply chains between North America and Asia (APGCI, 2013; Citizenship and Immigration Canada, 2010). While overall foreign undergraduate and graduate student growth continues to trend upwards, the $30 \%$ decline in the nation's largest foreign graduate student population should warrant attention moving forward, particularly as the international education market continues to become increasingly competitive. 


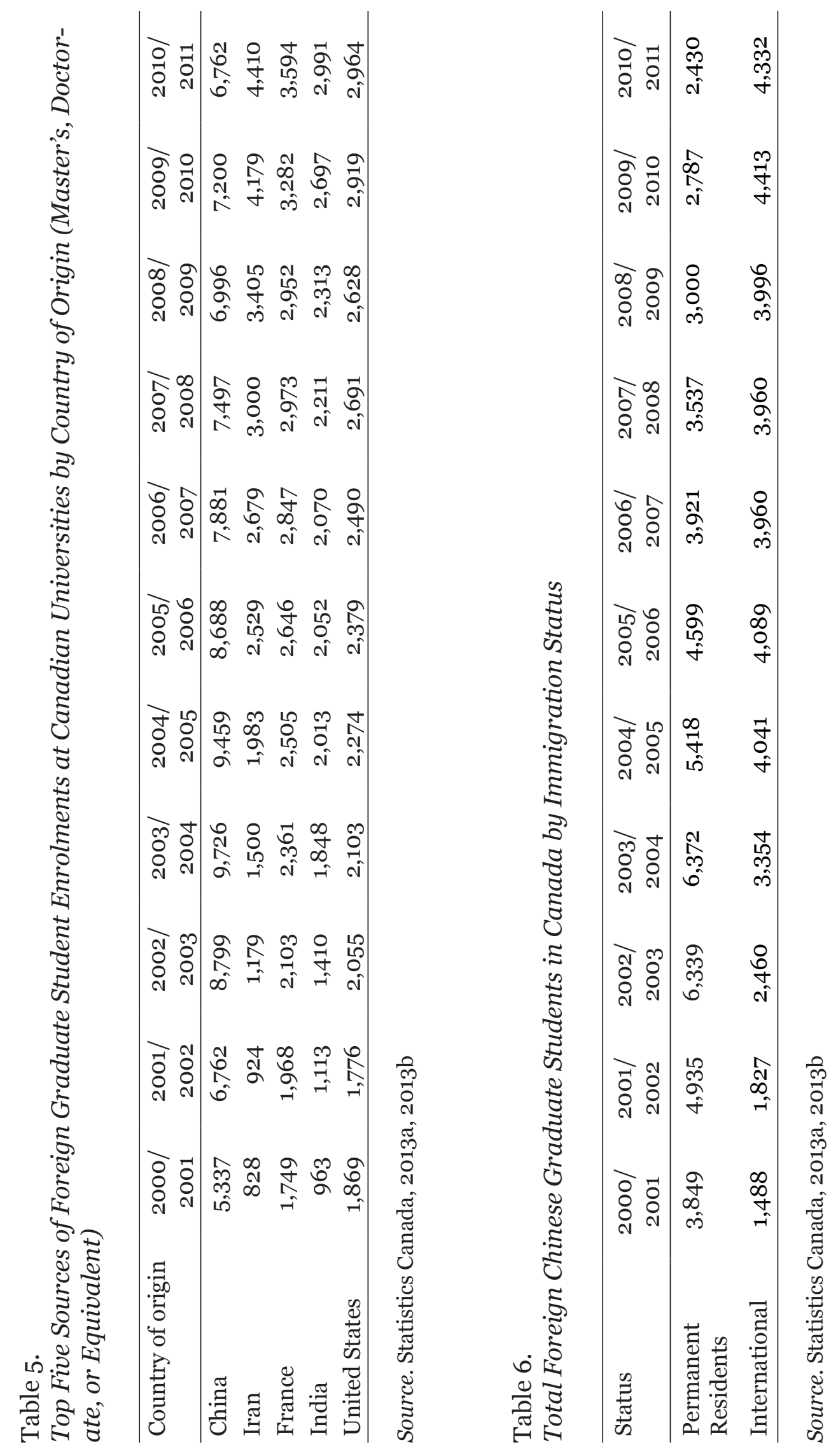




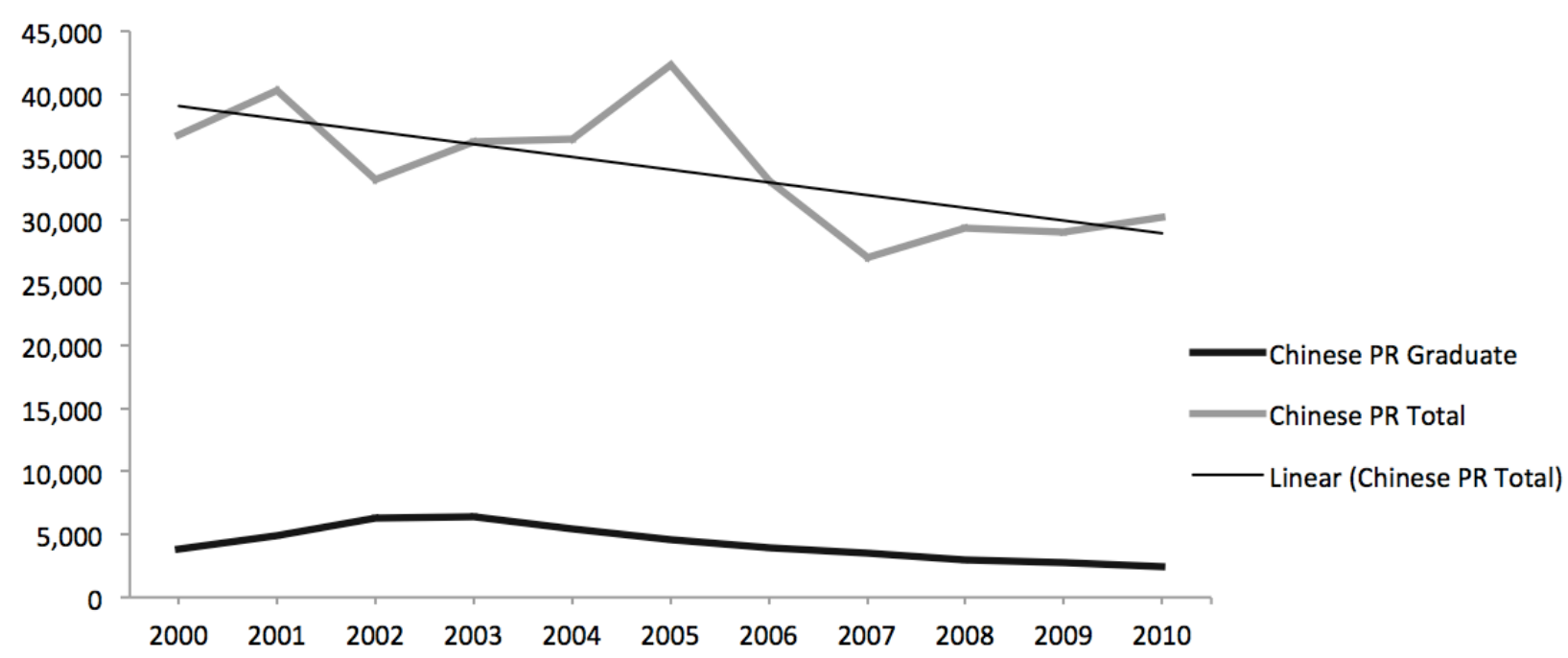

Figure 5. Chinese permanent resident trends in Canada (Citizenship and Immigration Canada, 2003, 2013; Statistics Canada, 2013a, 2013b)

\section{Challenges of Canadian Internationalization: Macro and Micro Perspectives}

\section{Macro Perspectives}

The promotion of the internationalization of higher education has not been without critique, particularly regarding the role it plays in the spread of (neo)colonial and neoliberal discourses from the west "outwards," and the standardization of English-mediated and Anglocentric epistemologies and ontologies, including a bias towards western-based knowledge creation, research methods, methodologies, and academic discourses. What constitutes "legitimate" research and knowledge has long been determined by colonial powers, who act as gatekeepers to academic communities, both within the west and outside it (Smith, 1999). Akena (2012) notes:

European colonizers have defined legitimate knowledge as Western knowledge, essentially European colonizers' ways of knowing, often taken as objective and universal knowledge. Arriving with the colonizers and influenced by Western ethnocentrism, Western knowledge imposed a monolithic world view that gave power and control in the hands of Europeans. It delegitimized other ways of knowing as savage, superstitious, and primitive. (p. 600)

The resulting "homogenization of academic culture" (Kubota, 2009) that English-mediated and western-based internationalization promotes thus contributes to the intensification of academic neocolonization in both study-abroad and home contexts for many foreign students (Altbach, 1971; Altbach \& Knight, 2007; Kubota, 2009; Mok, 2007). These issues can create challenges for students as they attempt to competitively (re)position themselves after returning home or in the global market place while negotiating their way in an Anglocentric and Eurocentric academic world. Alternatively, Steinman (2009) suggests that western universities and their instructors should move to establish 
more flexible and additive relationships with foreign students coming from non-Western academic traditions instead of expecting them to unilaterally morph into the conventions and practices of their new academic communities and discourses.

Another potential concern has been the perceived tension between rising foreign CLD student populations and the necessity to maintain rigorous admission and academic standards. In the UK, for example, it has been suggested that nearly two-thirds of recently admitted international undergraduate students might lack the language proficiency needed to thrive in classes (Paton, 2012). There have been related and highly charged discussions surrounding these enrolment trends and the potential preference that higher fee-paying international students may receive over more "qualified" (and culturally and linguistically advantaged) domestic students (Stanford, 2012; Watt \& Newell, 2012). Similar types of discussions are also occurring in the Canadian context, including a controversial opinion piece from the online magazine of the Association of Universities and Colleges of Canada, University Affairs, titled "Internationalizing the Canadian Campus: ESL Students and the Erosion of Higher Education" (Friesen \& Keeney, 2013). The authors, both Canadian professors at the time of the article's publication, argue that the challenges of underperforming "ESL students" in their classrooms outweigh any potential benefits:

There is no sugar-coated way to say this: many of those who are welcomed at our universities are simply unprepared for the rigours of the university classroom. . . . Instead of engaging students in disentangling the nuances and subtleties of a particularly important passage from the assigned readings, one begins speaking to the class as one might speak to academically challenged teenagers. ... Qualified students can hardly be blamed if they slouch in their seats and study their shoelaces, as the professor iterates, yet again, something they learned in grade school. . . Given our experience, we believe that Canadian universities need to rethink their enthusiasm for non-English-speaking students. (n.p.)

Although unrealistic, even hyperbolic, these opinions are certainly not unique in the broader discussion related to the increased presence of foreign students at Canadian universities. Recent articles in Maclean's ("The Flap over the Fluency Gap," MacQueen, 2013), The Vancouver Sun ("Foreign Students a New Cash Cow," Todd, 2013), and CBC ("U of R International Students Hurt by Lack of English Skills, Prof Says," CBC, 2013) highlight the growing debate over the potential language proficiency gaps of some foreign students and the compromising impact on Canadian higher education. Arguments such as this reflect a demographic frustrated with the shifting nature of Canadian education and the challenges that some foreign students and those around them can encounter. These opinions, however, also reflect an unbalanced perspective on the current realities of higher education in Canada, from the short-term economic and socio-educational benefits to the longer-term impacts surrounding the recruitment, training, and possible migration of talented incomers. From purely pragmatic, strategic, and economic perspectives, it makes little sense for Canadian universities to "rethink their enthusiasm for nonEnglish-speaking students" if this rethinking results in fewer students enrolling at Canadian universities.

A conspicuously lacking point in many of these heated discussions is not whether Canadian governments and universities should continue to recruit and enrol CLD foreign 
students in the first place but how stakeholders can and should work together to ensure foreign students are provided better opportunities to succeed and socialize within their local communities and discourse practices. Leask (2010) argues that many of the perceived barriers of foreign L2 students, such as the ones outlined above, impact domestic students' willingness to interact with foreign students in class-a reaction that limits foreign students' opportunities to acculturate into their university communities. Dialectical hierarchies that favour standardized forms of English over non-standard varieties may also serve as barriers for some foreign students who speak English as a first or native language but do not speak the dialect of preference in their university setting-issues that can apply to Canadian students as well. Steinman's (2009) call for a "flexible, additive intent rather than a prescriptive, subtractive one" (p. 164) regarding the socialization of foreign L2 students is also important here, in both a pedagogical as well as an epistemological sense. Pedagogically, an inclusive, adaptive approach can lessen potential tensions and misunderstandings by encouraging greater reflexivity, understanding, and communication between teachers and CLD students. This reflexivity and responsiveness can facilitate the possibility of further internationalizing course curricula and teaching and learning approaches. In this sense, both students and teachers (foreign and domestic alike) can achieve greater degrees of understanding and co-operation by being receptive to each others' perspectives while at the same time acknowledging and (co)constructing what types of academic expectations are typically preferred in their specific Canadian contexts. Epistemologically, a flexible, additive approach marks a shift away from Anglocentric and Eurocentric academic norms and practices that can serve as barriers for some foreign students and can position them as culturally and linguistically "deficient" compared to their domestic peers, instead of as active agents with valuable skills and knowledge of their own.

\section{Micro Perspectives}

Sometimes overlooked in broader macro-level discussions of the internationalization of higher education are the perspectives of the students themselves. There is a wide variety of research, some seemingly contradictory, that addresses international students' experiences in Canadian universities. The Canadian Bureau for International Education's (CBIE) 2009 national survey of postsecondary students reported overall satisfaction levels to be quite high for international university students, including the accessibility of professors, academic supports, and student advisors, for example. As a result, equally high numbers of students reported self-perceived successes in adjusting to the academic demands of their programs while in Canada. Grayson's (2008) survey of four Canadian universities found similar results for both domestic and international students, with $75 \%$ and $70 \%$ of students, respectively, reporting general satisfaction with their programs.

A significant body of research, on the other hand, has been more critical of the types of available supports and subsequent outcomes for international CLD students in Canada. The Association of Universities and Colleges of Canada reported that fewer than half of Canadian universities provided specific programs to sufficiently assist international students' social and academic well-being (AUCC, 2007). Examples of this lack of support have been well documented through a variety of qualitatively orientated studies at the tertiary level. Seror (2008), for example, reported on the struggles that Japanese L2 uni- 
versity students encountered when attempting to decode instructors' feedback on written academic assignments, and the potentially harmful ways such feedback can position or alienate students as deficient or "ESL" and in need of remedial support, as opposed to offering positive and affirming positionalities, such as those of "legitimate" or "autonomous" emerging scholars and professionals. Other foreign L2 students have reported struggling with academic reading and writing tasks due to the heavy demands of university course work, frustrations with receiving insufficient or confusing feedback from instructors, and oral fluency challenges during presentations and class discussions (Bronson, 2005; Cheng, Myles, \& Curtis, 2004; Jenkins, 2005; Lu \& Han, 2010; Zappa-Hollman, 2007). At times, L2 students may also speak less or write shorter and less-complex texts to try to decrease potential errors (Cheng, Myles, \& Curtis, 2004), and may rely on academic coping or rhetorical strategies like textual borrowing or patchwriting-which are often considered plagiarism in many western contexts, a view that may be at odds with some students' prior academic experiences (Pecorari, 2003; Polio \& Shi, 2012; Shi, 2004).

These varied perspectives suggest that although Canadian universities appear to be providing adequate opportunities for many foreign L2 students to succeed, there remains a considerable percentage who would benefit from more comprehensive and targeted academic support-support that can also benefit domestic English-speaking students who may require similar types of academic assistance. By further developing infrastructure that ensures students are able to access more precise academic assistance when needed, both domestic and foreign students alike will be better positioned to thrive during their time in Canadian universities and beyond.

\section{Conclusion}

Canada has experienced incremental growth in attracting foreign students to its universities; however, compared to other major destination countries, particularly in Europe, growth has been moderate, and even disappointing or underutilized for some (Davidson, 2012; Friesen, 2012). Although increasing foreign student populations has been a prominent talking point for the Canadian federal government of late, other countries, particularly non-OECD members, are also targeting these core demographics in hopes of growing numbers at their own universities (Sharma, 2012) and realizing the subsequent financial, social, and educational gains from such change. China, for example, the world's current largest exporter of students, has recently outlined its own aggressive goal to attract 500,000 students by 2020, up considerably from 328,000 in 2012 (Hu, 2014; Millar, 2012). These alternative destination spots, such as China, will be appealing for some internationally mobile students based on lower tuition fees and cost of living alone. The Canadian federal government has similarly announced its own lofty targets to double current international student numbers by 2022 (Foreign Affairs, Trade and Development Canada, 2012) - targets that will be increasingly difficult as alternative, and perhaps more economically viable, options emerge globally. As Saneh (2009) notes, "the face of higher education in North America is changing" (p. 169), and Canadian universities, educators, and students will need to better accommodate and adapt to such inevitable change instead of unfairly lamenting the "erosion" of Canadian higher education by the influx of "non-English-speaking students." Universities, after all, have an "academic and social responsibility in the local and global communities" (Kubota \& Abels, 2006, p. 82) to provide 
support and adapt to (and with) the students they so desperately seek. A failure to do so would be a failure not only to students but to the universities, their instructors, and the broader Canadian and international communities as well.

In my own current research project-a longitudinal, multiple-case study investigating the second-language socialization (Duff, 2010, 2012) of seven foreign Chinese PhD students at a large Canadian university-many challenges and frustrations similar to those presented above have emerged from my participants through in-depth interviews, narrative inquiry, and document analysis (Anderson, in preparation). Several of the students encountered various challenges acculturating into their respective academic literacies and discourses during their programs, experiencing vastly differing degrees of success. The pressures of negotiating their way into the English academy while maintaining high grades, writing comprehensive exams and dissertation proposals, presenting at conferences, and writing for publication (in several languages) can be overwhelming tasks for many graduate students, particularly in the context of highly competitive doctoral programs at tier-one research universities. Several findings from my study, in particular, are pertinent in the broader discussion of Canadian postsecondary internationalization. First, despite an increasing focus on issues related to the affective impact of teacher-directed feedback on students' academic writing tasks at the postsecondary level (e.g., Anderson, 2010; Bronson, 2005; Leki, 2006; Seror, 2008), too frequently the feedback that foreign L2 students receive on their academic writing is still misconstrued and insufficient. Instructors should continually reflect on their own practices and strive for more effective feedback strategies, particularly for L2 students who may require more thorough explanations and less ambiguous comments on their writing. Second, there is a crucial need for discipline-specific and level-appropriate academic writing support at universities to ensure all students are better prepared to learn the vocabulary, genres, registers, and conventions that are standard in their respective fields. Providing basic support for students in the form of writing centres or general writing courses may be missing the target, however well intentioned they are. In my study, several students reported seeking help from the university's writing centre, only to be disappointed and disillusioned by the lack of graduate-level assistance that was available. Those who attempted to access the writing centre's services were paired with undergraduate tutors, often from different disciplinary backgrounds than themselves, who lacked the ability to provide targeted and nuanced guidance for complex and technical academic writing tasks required at the graduate level.

Based on these findings, the following outlines several attainable and manageable supports that could ensure appropriate opportunities are available for struggling students who require them:

1. The development of faculty- or departmental-level peer-support networks or peer mentorships to serve both the academic and the social outcomes of students' experiences (Topping, 1996; Westwood \& Barker, 1990). This might include pairing incoming CLD students with senior-level students to facilitate both academic and linguistic support (if needed) as well as the exchange of knowledge, experience, and intercultural communication between pairs (Leask, 2010).

2. Reshaping university writing centres to offer discipline-specific content and genre knowledge (Mohamad \& Boyd, 2010) and level-appropriate support for both undergraduate and graduate students. 
3. Further refining university-provided academic support programs for struggling students to ensure discipline-based academic skills are being addressed (Baik \& Greig, 2009).

4. Organizing student-run writing groups in which students can share, collaborate, be inspired, and learn from each other (Li \& Vandermensbrugghe, 2011)

5. The facilitation and management of online departmental repositories that host samples of common professional and academic disciplinary genres that students will be expected to produce during their studies (and beyond, in some cases). These sample texts can act as guides or models for students unfamiliar with the specific conventions and practices that are standard in their content areas.

Several of the above suggestions should be appealing for cost-benefit purposes alone. Peer support, peer tutors, peer-run writing groups, and academic text repositories all require limited initial set-up and maintenance in terms of financial capital. Added to the academic benefits of these activities are the potential social benefits as new students, foreign and domestic alike, are provided opportunities to immediately connect to their fellow students. Peer support and its associated interactions can play vital roles in socializing students into their new programs and academic discourses. Minor investments in student support infrastructure could therefore entail both short- and long-term gains for universities. In the short term, students would be provided more opportunities to succeed, attrition rates might be lessened, and the quality of work would improve. In the long term, students' positive experiences would be more likely to translate into favourable reviews and reputations for their former programs and universities (Andrade, 2006; Carr, McKay, \& Rugimbana, 1999).

\section{Notes}

1. Foreign students refers to postsecondary students who are not citizens of the country where the data were collected.

2. International students refers to postsecondary students who have crossed a border with the express intention to study.

3. All figures in this paper have been converted to real 2013 Canadian dollars to adjust for inflation.

4. "Data for 2006-2007 [onwards] result from the modifications to the questionnaire (implementation of the Classification of Instructional Programs (CIP) for both undergraduate and graduate programs) and the expansion of the survey universe" (Statistics Canada, 2014a).

5. Internationalization of higher education refers to the process of global student and staff mobility, partnerships and cooperation between international higher education institutions (HEI), the proliferation of branch campuses and distance learning, and the associated intercultural and international impacts on curricula, teaching, and learning. (Knight, 2004, 2008).

6. OECD (Organisation for Economic Co-operation and Development) member countries for 2013 are as follows: Australia, Austria, Belgium, Canada, Chile, Czech Republic, Denmark, Estonia, Finland, France, Germany, Greece, Hungary, Iceland, Ireland, Israel, Italy, Japan, Korea, Luxembourg, Mexico, Netherlands, New Zealand, Norway, Poland, Portugal, Slovak Republic, Slovenia, Spain, Sweden, Switzerland, Turkey, 
United Kingdom, and the United States.

7. The following operationalizations are maintained throughout the paper for all data related to the discussion of Canadian higher education: (1) International students refers to students on a student visa who entered Canada with the sole purpose of studying at a Canadian university, those on diplomatic, trade, and other missions, and refugees. (2) Foreign students refers to "international students" and "permanent resident" students. (3) Canadian students refers to Canadian citizens. (4) The program types included are: undergraduate (first cycle), post-baccalaureate non-graduate program, graduate qualifying program (second cycle), health-related residency program, graduate program (second cycle), and graduate program (third cycle).

\section{Acknowledgements}

I would like to thank Dr. Patricia (Patsy) Duff and the anonymous reviewers for their invaluable suggestions on an earlier version of this paper. This research was supported by a Social Sciences and Humanities Research Council of Canada doctoral fellowship.

\section{References}

Akena, F. A. (2012). Critical analysis of the production of western knowledge and its implications for Indigenous knowledge and decolonization. Journal of Black Studies, 43(6), 599-619.

Altbach, P. (1971). Education and neocolonialism: A note. Comparative Education Review, 15(2), 237-239.

Altbach, P., \& Knight, J. (2007). The internationalization of higher education: Motivations and realities. Journal of Studies in International Education, 11(3-4), 290305 .

Anderson, T. (2010). The effects of tiered corrective feedback on second language academic writing. (Unpublished master's thesis). University of British Columbia, Vancouver, BC, Canada.

Anderson, T. (in preparation). Negotiating academic discourse practices, ideologies, and identities: The socialization of Chinese PhD students. (Dissertation in progress). University of British Columbia, Vancouver, BC, Canada.

Andrade, M. S. (2006). International students in English-speaking universities: Adjustment factors. Journal of Research in International Education, 5(2), 131-154.

APGCI (Asia-Pacific Gateway and Corridor Initiative). (2013). Retrieved from http:// www.asiapacificgateway.gc.ca

AUCC (Association of Universities and Colleges of Canada). (2007). Internationalizing Canadian campuses. Ottawa, ON: Author. Retrieved from http://www.aucc.ca/mediaroom/publications/internationalizing-canadian-campuses

Baik, C., \& Greig, J. (2009). Improving the academic outcomes of undergraduate ESL students: The case for discipline-based academic skills programs. Higher Education Research and Development, 28(4), 401-416. 
Bronson, M.C. (2005). Writing passage: Academic literacy socialization in ESL graduate students, a multiple case study. (Unpublished doctoral dissertation). University of California, Davis, CA.

Canadian Bureau for International Education (CBIE). (2009). Canada first: The 2009 survey of international students. Retrieved from http://www.cbie-bcei.ca/wp-content/ uploads/2011/10/Canada-First-20091.pdf

Carr, S. C., McKay, D., \& Rugimbana, R. (1999). Managing Australia's aid- and selffunded international students. International Journal of Education Management, 13(4), 167-172.

CAUT (Canadian Association of University Teachers). (2013). CAUT almanac of postsecondary education in Canada. Ottawa: Author.

CBC (Canadian Broadcasting Corporation). (2013, May 27). $U$ of $R$ international students hurt by lack of English skills, prof says. Retrieved from http://www.cbc.ca/ news/canada/saskatchewan/u-of-r-international-students-hurt-by-lack-of-englishskills-prof-says-1.1411866

Cheng, L., Myles, J., \& Curtis, A. (2004). Targeting language support for non-native English-speaking graduate students at a Canadian university. TESL Canada Journal, 21(2), 50-71.

Citizenship and Immigration Canada. (2003). Facts and figures 2003: Immigration overview-permanent and temporary residents. Retrieved from http://publications. gc.ca/collections/collection_2010/cic/Ci1-8-2003-eng.pdf

Citizenship and Immigration Canada. (2010). Government of Canada works to welcome more Chinese students to Canadian colleges. Retrieved from http://news.gc.ca/ web/article-en.do?m=/index\&nid=559599

Citizenship and Immigration Canada. (2011). Attracting and retaining international PhD students the focus of new initiative. Retrieved from http://news.gc.ca/web/articleen.do?nid $=635019 \&$ wbdisable $=$ true

Citizenship and Immigration Canada. (2013). Facts and figures 2012: Immigration overview-permanent and temporary residents. Retrieved from http://publications. gc.ca/collections/collection_2013/cic/Ci1-8-2012-eng.pdf

Davidson, P. (2012). From vision to action on expert panel report. Association of Universities and Colleges of Canada. Retrieved from http://www.aucc.ca/media-room/ news-and-commentary/from-vision-to-action-on-expert-panel-report

Duff, P. (2010). Language socialization into academic discourse communities. Annual review of applied linguistics, 30, 169-192.

Duff, P. (2012). Second language socialization. In A. Duranti, E. Ochs, \& B. Schieffelin (Eds.), Handbook of language socialization (pp. 564-586). New York, NY: Blackwell.

Foreign Affairs, Trade and Development Canada. (2011). Canada's capacity for international student enrollment. Retrieved from http://www.international.gc.ca/ education/capacity_report-rapport_sur_les_capacites.aspx?view=d 
Foreign Affairs, Trade and Development Canada. (2012). International education: A key driver of Canada's future prosperity. Retrieved from http://www.international. gc.ca/education/report-rapport/strategy-strategie/toc-tdm.aspx?lang=eng

Foreign Affairs, Trade and Development Canada. (2014). Canada's international education strategy: Harnessing our knowledge advantage to drive innovation and prosperity. Retrieved from http://international.gc.ca/global-markets-marchesmondiaux/education/strategy-strategie.aspx?lang=eng

Friesen, E. (2012, October 23). Quebec losing race to attract international students. McGill Tribune. Retrieved from http://mcgilltribune.com/quebec-losing-race-to-attractinternational-students/

Friesen, N., \& Keeney, P. (2013, August 7). Internationalizing the Canadian campus: ESL students and the erosion of higher education. University Affairs. Retrieved from http://www.universityaffairs.ca/opinion/in-my-opinion/internationalizing-thecanadian-campus/

Goddard, B. (2012). Future perspectives: Horizon 2025. In D. David \& B. Mackintosh (Eds.), Making a difference: Australian international education (pp. 398-414). Sydney, Australia: UNSW Press.

Grayson, J. P. (2008). The experiences and outcomes of domestic and international students at four Canadian universities. Higher Education Research \& Development, $27(3), 215-230$.

$\mathrm{Hu}$, D. (2014). International students in Chinese higher education: Choices, expectations, and experiences by region of origin (Unpublished master's thesis). Stanford University, Berkeley, CA, USA.

Jenkins, J.(2005).Implementing aninternationalapproachtoEnglish pronunciation: The role of teacher attitudes and identity. TESOL Quarterly, 39(3), 157-181.

Kiley, K. (2011, December 9). Occupy someone else. Inside Higher Ed. Retrieved from http://www.insidehighered.com/news/2011/12/o9/public-universities-question-whythey-not-lawmakers-are-protesters-target

Knight, J. (2008). Higher education in turmoil: The changing world of internationalization. Rotterdam, Netherlands: Sense Publishers.

Kubota, R. (2009). Internationalization of universities: Paradoxes and responsibilities. The Modern Language Journal, 93, 612-616.

Kubota, R., \& Abels, K. (2006). Improving institutional ESL/EAP support for international students: Seeking the promised land. In P. K. Matsuda, C. Ortmeier-Hooper, $\&$ X. You (Eds.), Politics of second language writing: In search of the promised land (pp. 75-93). West Lafayette, IN: Parlor Press.

Leask, B. (2010). "Beside me is an empty chair": The student experience of internationalisation. In E. Jones (Ed.), Internationalisation and the student voice: Higher education perspectives (pp. 3-18). New York, NY: Routledge. 
Leki, I. (2006). "You cannot ignore": L2 graduate students' response to disciplinebased written feedback. In K. Hyland \& F. Hyland (Eds.), Feedback in second language writing: Contexts and issues (pp. 266-285). New York, NY: Cambridge University Press.

Li, L. Y., \& Vandermensbrugghe, J. (2011). Supporting the thesis writing process of international research students through an ongoing writing group. Innovations in Education and Teaching International, 48(2), 195-205.

Lu, C., \& Han, W. (2010). Why don't they participate? A self-study of Chinese graduate students' classroom involvement in North America. Brock Education, 2O(1), 80-96.

MacQueen, K. (2013, November 1). The flap over the fluency gap. Maclean's. Retrieved from http://www2.macleans.ca/2013/11/o1/the-flap-over-the-fluency-gap/

Marginson, S. (1999). Harvards of the Antipodes? Nation building universities in a global environment. Access: Critical Perspectives on Cultural and Policy Studies in Education, 18(2), 1-20.

Millar, M. (2012, June 11). Go East, young person. BBC News. Retrieved from http:// www.bbc.co.uk/news/business-18277682

Mohamad, M., \& Boyd, J. (2010). Realizing distributed gains: How collaboration with support services transformed a basic writing program for international students. Journal of Basic Writing, 29(1), 78-98.

Mok, K. H. (2007). Questing for internationalization of universities in Asia: Critical reflections. Journal of Studies in International Education, 11(3-4), 433-454.

OECD. (2009). Higher education to 2030. Volume 2: Globalisation. Retrieved from http://www.oecd.org/edu/ceri/highereducationto2030volume2globalisation.htm

OECD. (2013a). Education at a glance 2013: OECD indicators. Retrieved from http:// www.oecd.org/edu/eag.htm

OECD. (2013b). Table C4.7. Number of foreign students in tertiary education, by country of origin and destination (2011), and market shares in international education (200O, 2011). Retrieved from http://dx.doi.org/10.1787/888932850851

OECD. (2014). Education at a glance 2014: OECD indicators. Retrieved from http:// www.oecd.org/edu/eag.htm

Paton, G. (2012, August 24). Universities "admitting foreign students with poor English". The Telegraph. Retrieved from http://www.telegraph.co.uk/education/ universityeducation/9497191/Universities-admitting-foreign-students-with-poorEnglish.html

Pecorari, D. (2003). Good and original: Plagiarism and patchwriting in academic second-language writing. Journal of Second Language Writing, 12(4), 311-424.

Polio, C., \& Shi, L. (2012). Perceptions and beliefs about textual appropriation and source use in second-language writing. Journal of Second Language Writing, 21, 95-101.

Roslyn Kunin \& Associates. (2012). Economic impact of international education in Canada-an update: Final report. Retrieved from http://www.international.gc.ca/ education/report-rapport/economic-impact-economique/index.aspx 
Saneh, N. A. (2009). Intercultural rhetoric in higher education: The case of Iranian students' textual practices in North American graduate schools (Unpublished doctoral dissertation). University of Ottawa, Ottawa, ON, Canada.

Seror, J. (2008). Socialization in the margins: Second language writers and feedback practices in university content courses (Unpublished doctoral dissertation). University of British Columbia, Vancouver, BC, Canada.

Sharma, Y. (2012, August 14). Foreign students are part of "soft power", but targets are ambitious. University World News. Retrieved from http://www.universityworldnews. com/article.php?story $=20120814135723490$

Shi, L. (2004). Textual borrowing in second language writing. Written Communication, 21, 171-200.

Smith, L. T. (1999). Decolonizing methodologies, research and indigenous peoples. Dunedin, New Zealand: University of Otago Press.

Stanfield, D., \& Shimmi, Y. (2012). Chinese higher education: Statistics and trends. International Briefs for Higher Education Leaders, 1, 5-6.

Stanford, P. (2012, June 29). Our universities fall for the glitter of foreign gold. The Telegraph. Retrieved from http://www.telegraph.co.uk/education/ universityeducation/9364913/Our-universities-fall-for-the-glitter-of-foreign-gold.html

Statistics Canada. (n.d.). Table 477-0058-Financial information of universities and degree-granting colleges, revenues by type of funds, annual (dollars) [CANSIM database]. Available from http://www5.statcan.gc.ca/cansim/home-accueil?lang=eng

Statistics Canada. (2013a). Custom table: PSIS 2013-O51 by university enrolments from 200O-2010 by Canadian students. Postsecondary Student Information System. Ottawa, ON: Author.

Statistics Canada. (2013b). Custom table: PSIS 2013-O51 by university enrolments from 2000-2010 by international students. Postsecondary Student Information System. Ottawa, ON: Author.

Statistics Canada. (2014a). Custom table 8E: Weighted average tuition fees for full-time undergraduate and graduate Canadian students. Postsecondary Student Information System. Ottawa, ON: Author.

Statistics Canada. (2014b). Custom table 9E: Weighted average tuition fees for full-time undergraduate and graduate international students. Postsecondary Student Information System. Ottawa, ON: Author.

Steinman, L. (2009). Academic writing and the international imperative. Collected essays on Learning and Teaching, 2, 33-39.

Thompson, J., \& Bekhradnia, B. (2010). The independent review of higher education funding: An analysis. Oxford, UK: Higher Education Policy Institute.

Todd, D. (2013, November 30). Foreign students a new cash cow. The Vancouver Sun.

Topping, K. J. (1996). The effectiveness of peer tutoring in further and higher education: A typology and review of the literature. Higher Education, 32(3), 321-345. 
Watt, H., \& Newell, C. (2012, June 26). How foreign students with lower grades jump the university queue. The Telegraph. Retrieved from http://www.telegraph.co.uk/ education/universityeducation/9357875/How-foreign-students-with-lower-gradesjump-the-university-queue.html

Westwood, M. J., \& Barker, M. (1990). Academic achievement and social adaptation among international students: A comparison groups study of the peer-pairing program. International Journal of Intercultural Relations, 14(2), 251-263.

Zappa-Hollman, S. (2007). Academic presentations across post-secondary contexts: The discourse socialization of non-native English speakers. Canadian Modern Language Review, 63, 455-485.

\section{Contact Information}

Tim Anderson

Department of Language and Literacy Education

University of British Columbia

tanders@mail.ubc.ca

Tim Anderson is a sessional instructor and doctoral candidate in the Department of Language and Literacy Education at the University of British Columbia. He teaches courses in applied linguistics for teachers and conducts research on the teaching and learning of English and Chinese as additional languages, the internationalization of higher education, and transnationalism. His dissertation focuses on the academic discourse socialization of foreign Chinese doctoral students in Canada. 